\title{
Productivity Evaluation of Cassava (Manihot esculenta Crantz) Cultivated with Different Fertilizers
}

\author{
Lucas Simongini \\ Biotechnology Department, Post-Graduate Program in Biotechnology Applied to Agriculture, \\ Paranaense University, Umuarama, Paraná, Brazil
}

\section{Wesley Ribeiro Rivadavea}

Universidade Paranaense - UNIPAR, Campus III. Avenida Tiradentes, 3240 - Jardim Paraíso, Umuarama, PR, Brazil

\section{Julliane Destro de Lima}

Biotechnology Department, Post-Graduate Program in Biotechnology Applied to Agriculture, Paranaense University, Umuarama, Paraná, Brazil

\section{Willian Gonçales Penasso, Jefferson Alan Teixeira}

Universidade Paranaense - UNIPAR, Campus III. Avenida Tiradentes, 3240 - Jardim Paraíso, Umuarama, PR, Brazil

\section{Daisy Leticia Ramirez Monzon}

Faculty of Agronomic Engineering. Universidad Nacional del Este, Minga Guazú, Paraguay, Paraguay

Pedro Henrique Riboldi Monteiro

Doctor in Forest Engineering, Brazil

Glacy Jaqueline da Silva

Biotechnology Department, Post-Graduate Program in Biotechnology Applied to Agriculture, Paranaense University, Umuarama, Paraná, Brazil 
Received: July 18, 2021 Accepted: August 10, 2021 Published: August 12, 2021

doi:10.5296/jas.v9i3.18870

URL: https://doi.org/10.5296/jas.v9i3.18870

\begin{abstract}
Cassava is one of the most important socio-economic crops in the world. It is usually cultivated in soils with low fertility and little mechanization, which makes it difficult to increase the crop's productivity and, consequently, economic gains. The aim of this study was to evaluate different types of fertilization (Poultry litter, organomineral fertilizer and rooting) in cassava cultivation in the northwest region of the state of Paraná - Brazil. After 10 months of planting, the variables evaluated were: number of roots, root diameter, root length, shoot height, starch yield and shoot fresh weight. The results were submitted to mean test, principal component analysis and Pearson's R correlation analysis. The results showed that poultry litter presented the best result in practically all the evaluated variables, followed by rooting, which promoted the highest number of roots; in addition, with the exception of the number of roots, all other variables were highly correlated.
\end{abstract}

Keywords: poultry litter, organomineral, organic fertilizer, rooter

\title{
1. Introduction
}

\subsection{Manihot Escullenta Crantz.}

Cassava (Manihot esculenta Crantz) is a tuberous plant, of the Euphorbiaceae family, and has Brazil as a possible center of origin and diversification of the cultivated species. (Abraham, 1970; Fukuda et al., 2005). The great importance of this culture is due to the fact that about half a billion people around the world have cassava as a primary source of carbohydrates (Isendahl, 2011). In Brazil, studies show that 59\% of the population consume this tuber at least every two days (Horodyska et al., 2021). This is a considerable amount, especially when we talk about cassava production. There are two types of cassava grown in Brazil. Wild cassava (requires detoxification for human consumption and is widely used for the production of flour) and does not require fertile soil for production; and sweet cassava (suitable for human consumption and requires fertile soil for production) (Fraser, 2010).

\subsection{Culture Production and Needs}

The cultivation of cassava has an extreme energy importance not only in Brazil, but in the world. In 2019, FAO data estimate that there was a production of 303568814 tons, with crops spread from Africa, Asia, to the Americas. Brazil is the third largest producer, with a production of 17497115 tons, being the first within the Americas (FAO, 2019). Although this number is expressive, when we look at a historical scenario, this is the smallest production from Brazil in history. In the 70's, the country was the biggest producer in the world, with a production close to 30 million tons/year.

This loss of hegemony in cultivation is mainly due to the increase in technological advances in the production of soy and maize, together with the low marketing prices of cassava 
(Groxco, 2020). The state of Paraná is the second largest Brazilian producer (IBGE, 2019) and has about 59\% of all starch industries in Brazil, which are located in the west and northwest of the state.

This fact makes the culture very interesting in these locations, as the cost of transport is quite advantageous. The northwest of the Paraná state has soil from the "Arenito Caiuá" formation, which is characteristic of sandy soil with low organic matter content (Gasparetto, 1999).

Cassava grows well in sandy and acidic soils as it supports high levels of aluminum. However, it expresses high productivity in fertile soils (Rós et al., 2013). Looking to achieve better yields in this region, farmers are seeking to use inputs that replace chemical fertilization, such as rooting and organic/mineral products. In order to evaluate fertilization systems that may be economically viable for the farmer, this study aims to evaluate the yield of cassava under 3 different types of fertilization in the northwest region of Paraná state.

\section{Method}

\subsection{Experimental Area}

The study was carried out in the city of Tapejara, (Latitude: $25^{\circ} 58^{\prime} 43^{\prime \prime}$ South, Longitude: $52^{\circ} 48^{\prime} 47^{\prime \prime}$ West), midwest region of Paraná State, Brazil. The region's soil is classified as dystrophic red latosol (Oxisoil), and its rock formation is "Arenito Caiuá" (Bhering et al., 2007).

\subsection{Soil Preparation, Sowing and Cultivation}

The experiment occurred in the 2018/2019 harvest. In the month 04/2018, a chemical analysis of the soil was performed and 3 months before planting, there was the incorporation of calcitic calcium for acidity correction, according to the soil needs. 08/2018 on the ground was prepared with harrowing and plowing the same day in which there was the manual planting.

The cultivar used in this study was IAC 15 . This cultivar is classified as sweet cassava and is considered a super-early variety. The cuttings were manually chopped at a size of $12 \mathrm{~cm}$ each, and were planted sequentially in holes with $8 \mathrm{~cm}$ deep, a spacing of $55 \mathrm{~cm}$ between plants and $85 \mathrm{~cm}$ between lines.

Every 50 days, manual weeding and spraying with baculovirus were performed for preventive biological control of caterpillars.

\subsection{Experimental Treatments}

The experimental design was divided into 4 treatments, including the control. The treatments were: T1 (amino acid-based rooting); T2 (chemical fertilizer); T3 (poultry litter) and T4 (control, without adding any fertilizer).

In the $\mathrm{T} 1$ treatment, the cuttings were immersed in the rooting solution for 5 minutes, according to the manufacturer's recommendation. The commercial rooting used is based on molybdenum trioxide (Mo: 14\%) and potassium hydroxide (K: 12\%); in the T2 treatment, the 
chemical analysis of the soil indicated the need to incorporate $250 \mathrm{~kg}$ of fertilizer per hectare. The fertilizer used had an organomineral formulation of 4-14-8 NPK, which was linearly distributed in the planting holes; in the T3 treatment, 4 tons per hectare were broadcasted, according to the culture recommendation, of poultry litter throughout the plot. The poultry litter had the following composition: $\mathrm{N}: 4.7 \%, \mathrm{P}: 2.28 \%, \mathrm{~K}: 4.6 \%, \mathrm{Ca}: 1.8 \%, \mathrm{Mg}: 0.5 \%$ and $83 \%$ organic matter; treatment $\mathrm{T} 4$ had only the correction initially made with calcitic limestone and was identified as a control.

\subsection{Parameters Evaluated}

After 10 months of planting, the lateral lines of each treatment were excluded and 25 plants per treatment were randomly collected, totaling 100 plants. After tuber collection, the following parameters were evaluated: Number of roots per plant, diameter of roots $(\mathrm{cm})$, length of roots $(\mathrm{cm})$, height of shoot $(\mathrm{cm})$, fresh weight of aerial part $(\mathrm{kg})$ (FWAP) and starch yield. To obtain the starch yield, a $5 \mathrm{~kg}$ hydrostatic balance was used. For this, $5 \mathrm{~kg}$ of roots were weighed, which were then placed in a basket immersed in water, coupled to an analytical balance. Thus, the weight of the tubers, free from starch, was obtained.

\subsection{Statistical Analysis}

The experimental design was conducted completely randomized (DIC), with 25 repetitions and 4 treatments, totaling 100 experimental units.

\subsubsection{Average Analysis}

The results were submitted to statistical analysis, through comparison of means by the Tukey method with 5\% probability. The program used was ASSISTAT (2017).

\subsubsection{Principal Component Analysis (PCA)}

It was performed a multivariate exploratory analysis to determine the principal component analysis (PCA), which allowed the joint evaluation of characteristics evaluated in all the four treatments. The result of the analysis was presented in a Biplot graphic, which help to characterize the groups of analyzed variables (Moita Neto and Moita, 1998). All evaluated characteristic was transformed into an orthogonal latente variable called principal component, which generate a linear combination of the original variables created with the eigenvalues of the covariance matrix data (Hair et al., 2009). The analysis was performed using the Statistic 13.3 software.

\subsubsection{Pearson’s Correlation Coeficient Estimative (r)}

The results were submitted to Pearson's correlation coefficient estimate (r) which allowed to quantify the degree of association between two variables. The variation ranges from -1 to 1 and the highest correlation occurs in the most approximate values of these, both positive and negative value. From this it was possible to evaluate the models of simple genotypear regression. An Euclidean distance matrix was obtained from the grouping by Ward's method. These data were generated from the Statistic 7 program. 


\section{Results}

\subsection{Average Evaluation}

Table 1 shows the results obtained from the mean comparison analysis. It is possible to verify that for the plant height parameter, the tallest plants were those of the T3 treatment (poultry litter), followed by the $\mathrm{T} 1$ treatment (rooter) and the plants with the smallest height were those of the control (T4). For the variable number of roots, the treatment with the largest number of roots was $\mathrm{T} 1$, while treatments $\mathrm{T} 2, \mathrm{~T} 3$ and $\mathrm{T} 4$ did not obtain statistical difference for this variable. For the variable FWAP treatment T3, considered the one with the highest fresh weight of aerial part, had 20\% more FWAP than treatment T1, 37\% more than treatment $\mathrm{T} 2$ and $131 \%$ more than treatment $\mathrm{T} 4$. For the variable root weight, treatment $\mathrm{T} 3$ obtained the highest value, being 11\% higher than T1, 29\% higher than T2 and 52\% higher than T4. For root diameter, treatment T3 was the one that obtained plants with the largest diameter, while the other treatments did not obtain statistical difference between them. For root length, T3 treatment was superior to all other treatments. For the starch yield variable, treatment T3 was superior to all other treatments, with T1 having the second highest starch yield, followed by T2 and finally, the lowest starch yield value was obtained in treatment T4.

Table 1. Variable means obtained through tukey analysis, with 5\% significance. The analysed variable are: plant height, number of roots, fresh weight of aerial part (FWAP), root weight, diameter and length and starch yield

\begin{tabular}{|c|c|c|c|c|c|c|c|}
\hline Treatment & $\begin{array}{l}\text { Plant } \\
\text { height }\end{array}$ & $\begin{array}{l}\text { Number } \\
\text { of roots }\end{array}$ & FWAP & $\begin{array}{c}\text { Root } \\
\text { weight }\end{array}$ & $\begin{array}{c}\text { Root } \\
\text { diameter }\end{array}$ & $\begin{array}{c}\text { Root } \\
\text { length }\end{array}$ & $\begin{array}{c}\text { Starch } \\
\text { yield }\end{array}$ \\
\hline $\mathbf{T 1}$ & $2.17 \mathrm{~b}$ & $2.95 \mathrm{a}$ & $2.22 \mathrm{~b}$ & $2.34 \mathrm{~b}$ & $0.20 \mathrm{~b}$ & $0.22 \mathrm{~b}$ & $0.74 \mathrm{~b}$ \\
\hline $\mathbf{T} 2$ & $1.89 \mathrm{c}$ & $2.14 \mathrm{~b}$ & $\begin{array}{c}1.74 \\
\mathrm{c}\end{array}$ & $\begin{array}{c}1.88 \\
\mathrm{c}\end{array}$ & $0.20 \mathrm{~b}$ & $\begin{array}{c}0.16 \\
\mathrm{c}\end{array}$ & $0.73 \mathrm{c}$ \\
\hline T3 & $2.51 \mathrm{a}$ & $1.89 \mathrm{~b}$ & $2.78 \mathrm{a}$ & $2.65 \mathrm{a}$ & $0.25 \mathrm{a}$ & $0.28 \mathrm{a}$ & $0.77 \mathrm{a}$ \\
\hline $\mathbf{T 4}$ & $1.68 \mathrm{~d}$ & $1.94 \mathrm{~b}$ & $1.20 \mathrm{~d}$ & $1.27 \mathrm{~d}$ & $0.19 \mathrm{~b}$ & 0.12 c & $0.72 \mathrm{~d}$ \\
\hline $\mathrm{VC} \%$ & 3.53 & 8.53 & 5.45 & 5.28 & 5.93 & 12.72 & 0.62 \\
\hline
\end{tabular}

* Different letters in the column differ statistically from each other.

\subsection{Principal Component Analysis (PCA)}

The PCA analyzes (Figure 1) were divided into 2 factors, which explained $99.65 \%$ of the results. The PCA shows that treatments $\mathrm{T} 2$ and $\mathrm{T} 4$, located in the same quadrant (bottom right) had no influence on any evaluated characteristic. All evaluated treatments were directed to the right quadrants, and, with the exception of the number of roots, which was 


\section{Macrothink}

directly influenced by treatment $\mathrm{T} 1$, all other evaluations were directly influenced by treatment 3 (T3).

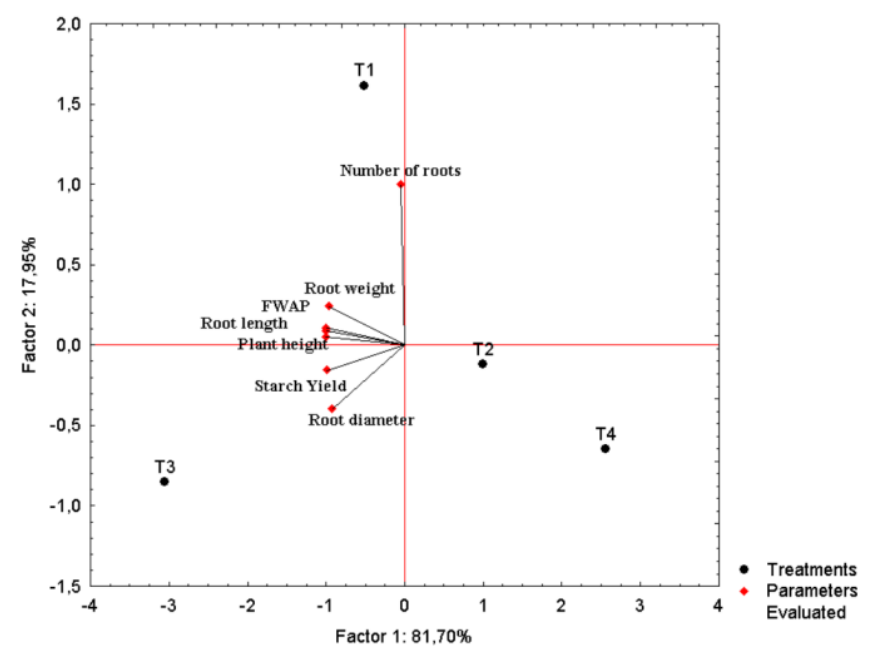

Figure 1. Biplot of principal component analysis scores and loadings for all the characteristics evaluated regarding the treatments. (T1): rooter; (T2): organomineral fertilizer; T3: poultry litter (T4): control

\subsection{Pearson's Correlation Coeficient Estimative ( $r$ )}

Pearson's correlation analysis (Table 2) shows a high correlation between all evaluated variables, except for number of roots $\mathrm{x}$ all other evaluated variables. We consider high correlation, both positive and negative, for all results between 0.7 and 1 (high positive correlation) and -0.7 and -1 (high negative correlation). In this study, all high correlations were between 0.78 (root weight and root diameter) and 0.99 (root length and plant height).

Table 2. Pearson's R correlation analysis considering all variables evaluated: plant height, number of roots, FWAP, root weight, diameter and lenght and starch yield.

\begin{tabular}{lccccccc}
\hline & $\begin{array}{c}\text { Plant } \\
\text { height }\end{array}$ & $\begin{array}{c}\text { Number } \\
\text { of roots }\end{array}$ & FWAP & $\begin{array}{c}\text { Root } \\
\text { weight }\end{array}$ & $\begin{array}{c}\text { Root } \\
\text { diameter }\end{array}$ & $\begin{array}{c}\text { Root } \\
\text { length }\end{array}$ & $\begin{array}{c}\text { Starch } \\
\text { yield }\end{array}$ \\
\hline Plant height & 1,000 & & & & & \\
$\begin{array}{l}\text { Number of } \\
\text { roots }\end{array}$ & 0,097 & 1,000 & & & & & \\
FWAP* & 0,995 & 0,149 & 1,000 & & & \\
Root weight & 0,969 & 0,278 & 0,988 & 1,000 & & \\
$\begin{array}{l}\text { Root } \\
\text { diameter }\end{array}$ & 0,897 & $-0,353$ & 0,869 & 0,788 & 1,000 & & \\
\hline Root length & 0,999 & 0,136 & 0,995 & 0,974 & 0,879 & 1,000 & \\
Starch yield & 0,978 & $-0,110$ & 0,961 & 0,908 & 0,969 & 0,970 & 1,000 \\
\hline
\end{tabular}

*FWAP - fresh weight of aerial part. 


\section{Discussion}

The use of poultry litter as a fertilizer is an efficient, cheap and promising strategy for cassava cultivation. Among its advantages we can mention the benefit provided to phosphorus (P), which, due to its organic base, penetrates deeper into the soil, compared to mineral sources, being readily solubilized and remaining available to the plant more easily (Cakmak, 2002). A recent study showed that trying to recover a saline soil with poultry litter (and other treatments) resulted in higher enzyme activity, in addition to an increase in soil organic carbon, total $\mathrm{N}$ and organic phosphorus (Xie et al., 2021).

Another important fator is the organic matter content of poultry litter. Organic matter is responsible for providing greater physical, chemical and microbiological balance in the soil, increasing porosity, reducing soil density and temperature, improving water retention and increasing the amount of microorganisms that decompose organic matter (Bhogal et al., 2009; Mazeika et al., 2021). A recent study showed that soil treated with poultry litter (heat treated) and poultry litter (no heat treatment) were the treatments that most changed the microbiological composition of the soil, compared to unfertilized control, NPK fertilizer, and NPK fertilizer combined with poultry litter (Peng et al., 2021), showing the benefit that poultry litter exerts on the soil microbiota. Another benefit is the increase in base saturation in soils due to the contribution of basic cations present at poultry litter. The results found by Donini (2011) are very similar to the results found in this study, which show that poultry litter clearly interfered with the soil, providing better conditions to obtain higher yields.

Several studies point to a nutritional contribution and development of cultures similar to the chemical contribution, when it comes from poultry litter. When comparing the growth, development and yield of pepper (Capsicum mannuum) with a chemical NPK-based fertilizer treatment, this crop obtained the same values of growth, days to flowering and harvesting as the chemical (Kunene et al., 2019). A result similar to the results found with fertilization with chemical NPK are already sufficient for the adoption of poultry litter, since, economically, chemical fertilization is much more costly. A local price survey showed that chemical fertilization is usually $93 \%$ more expensive than fertilization with poultry litter.

On the other hand, many studies prove a better nutritional contribution to plants, with a consequent increase in productivity after the plant develops in soil with fertilization with poultry litter. In a study that evaluated maize crop in an integrated crop-livestock system, grain yield showed a significant increase due to the addition of organic fertilization based on poultry litter (Novakowiski, 2013). In another study conducted in a soil with low CTC (cation exchange capacity), poultry litter provided increased productivity in cassava cultivars, when compared to the chemical fertilizer NPK (Rós et al., 2013). Another study showed an increase in productivity of $54 \%$ in cassava grown with poultry litter, compared to NPK fertilizer (Nilnoree et al., 2016).

In a study that aimed to evaluate carrot (Daucus carota) yield under different types of fertilization, poultry litter produced higher root yield, as a consequence of greater input of organic carbon in the soil, N, P, K, Ca, Mg and percentage of saturation of base, provided by the fertilization (Poku et al., 2014). This result also helps to explain the high correlation of 
practically all treatments evaluated in our study, because when nutrients are more easily available to the plant, the plant tends to have better quality, tends to develop more, reaching higher productivity.

The use of organic fertilizers in agriculture has become an important way of conserving soil quality, since organic sources have slow and gradual decomposition, solubilization of organic material, compared to chemical fertilizers, in addition to having essential nutrients for soil health, such as Nitrogen (N), Phosphorus (P), Potassium (K), Calcium (Ca), Magnesium (Mg) Sulfur (S), Zinc (Zn) Boron (B) Copper (Cu) and Molybdenum (Mb) (Vilela, 2009). Furthermore, the use of these organic sources contributes to a subsidy for the final destination of agricultural by-products. With this in mind, and taking the fantastic results obtained in this study as an example, we are increasingly recommending studies with these compounds, such as poultry litter, so that they can be used more and more in agriculture, significantly contributing to a productive and sustainable agriculture.

\section{Conclusion}

The use of poultry litter is recommended to produce the IAC 15 cultivar under the evaluated soil conditions, at the Arenito Caiuá.

\section{Acknowledgement}

This work was supported by: Coordenação de Aperfeiçoamento de Pessoal de Nível Superior (CAPES), Conselho Nacional de Desenvolvimento Científico e Tecnológico (CNPq) and Fundação Araucária.

\section{References}

Abraham, A. (1970). Breeding work in tapioc (cassava and new other tropical tuber crops). In Intemational Symposium on Tropical Root and Tuber Crops, Honolulu, 7679.

ASSISTAT. (2017). Assistência estatística. Available in: http://www.assistat.com/indexp.html

Bhogal, A., Nicholson, F. A., \& Chambers, B. J. (2009). Organic carbon additions: effects on soil bio-physical and physico-chemical properties. Eur. J. Soil Sci., 60(2), 276-286. https://doi.org/10.1111/j.1365-2389.2008.01105.x

Cakmak, I. (2002). Plant nutrition research: priorities to meet human needs for food in sustainable ways. Plant Soil, 247, 3-24. https://doi.org/10.1023/A:1021194511492

Donini, J. V. S. (2011). Características químicas de um Latossolo Vermelho Amarelo sob aplicação de cama de frango em complemento à adubação mineral. Universidade Federal de Mato Grosso (UFMT), Brazil. 40 pp. (M.Sc. Thesis: tropical agriculture).

FAO - Food and Agricultural Organization. FAOSTAT. Available in: http://www.fao.org/faostat/en/\#search/Cassava

Fraser, J. A. (2010). The diversity of bitter manioc (Manihot esculenta Crantz) cultivation in a whitewater Amazonian landscape. Diversity, 2(4), 586-609. https://doi.org/10.3390/d2040586 
Fukuda, W. M. G., de Oliveira, R. P., Fialho, J. D. F., Cavalcanti, J., Cardoso, E. M. R., Barreto, F., \& Costa, I. R. S. (2005). Germoplasma de mandioca (Manihot esculenta Crantz) no Brasil. Embrapa Semiárido - ALICE. 14pp.

Gasparetto, N. V. L. (1999). As formações superficiais do noroeste do Paraná e sua relação com o Arenito Caiuá. Universidade de São Paulo (USP), Brazil, 209pp. (DSc Thesis: geochemistry and geotectonics .

Groxko, M. (2019). Mandioca - Análise de conjuntura. Departamento de Economia Rural (DERAL). Available in: https://www.agricultura.pr.gov.br/sites/default/arquivos_restritos/files/documento/2019-12/M andioca\%202020.pdf

Horodyska, J., Pigat, S., Wonik, J., Bompola, F., Cai, D., Rehm, C. D., \& Gonzalez, T. D. (2021). Impact of sociodemographic factors on the consumption of tubers in Brazil. Nutr. J., 20(1), 1-10. https://doi.org/10.1186/s12937-021-00709-1

IBGE - Instituto Brasileiro de Geografia e Estatistica. Census of Agriculture in the field. Available in: https://www.ibge.gov.br/busca.html?searchword=censo\&searchphrase=all\&filtro=estat\&start $=11480$

Isendahl, C. (2011). The domestication and early spread of manioc (Manihot esculenta Crantz): a brief synthesis. Lat. Am. Antiq., 22(4), 452-468. https://doi.org/10.7183/1045-6635.22.4.452

Jaqueline, H. N., Itacir, E. S., Margarete, K. F., Anibal, M., \& Jackson, H. N. (2013). Adubação com cama de aviário na produção de milho orgânico em sistema de integração lavoura-pecuária. Semina. Ciênc. Agrárias., 34(4), 1663-1672. https://doi.org/10.5433/1679-0359.2013v34n4p1663

Kunene, T. R., Masarirambi, M. T., Wahome, P. K., \& Oseni, T. O. (2019). Influence of kraal manure, poultry litter and inorganic fertilizer on growth, yield and post-harvest quality of pepper (Capsicum annuum L.) in a sub-tropical environment. Asian J. Agric. Res., 1-11. https://doi.org/10.9734/ajaar/2019/v11i130043

Mažeika, R., Arbačiauskas, J., Masevičienè, A., Narutytè, I., Šumskis, D., Žičkienė, L., \& Baltrusaitis, J. (2021). Nutrient dynamics and plant response in soil to organic poultry litter-based fertilizers. Waste Biomass Valorization.

https://doi.org/10.1007/s12649-020-00978-7

Nilnoree, T., Anusontpornperm, S., Thanachit, S., Kheoruenromne, I., \& Petprapai, P. (2016). Effect of Poultry litter and organic wastes from cassava starch manufacturing plant on cassava grown on Dan Khun Thot soil. Kaen Kaset., 44, 167-78.

Peng, S., Wang, Y., Chen, R., \& Lin, X. (2021). Poultry litter and mushroom residues affect soil bacterial community structure but not the bacterial resistome when applied at the same rate of nitrogen for 3 years. Front. Microbiol., 12. https://doi.org/10.3389/fmicb.2021.618693 


\section{Al Macrothink}

Journal of Agricultural Studies

ISSN 2166-0379 2021, Vol. 9, No. 3

Poku, P. A., Agyarko, K., Dapaah, H. K., \& Dawuda, M. M. (2014). Influence of mucuna pruriens green manure, NPK and poultry litter amendments on soil physico chemical properties and growth and yield of carrot (Daucus carota L.). Int. J. Agric. Environ., 5, 26-44.

Rós, A. B., Hirata, A. C. S., \& Narita, N. (2013). Produção de raízes de mandioca e propriedades química e física do solo em função de adubação com esterco de galinha. Pesq. Agropec. Trop, 43(3), 247-254.

Vilela, L. A. F., Portugal, A. F., Carballal, M. R, Ribeiro, D. O., Araújo, A. B., Bosqueiro, M., \& Rossi, M. (2000). Estudos dos reguladores vegetais de Stimulate ${ }^{\circledR}$ no desenvolvimento e produtividade do feijoeiro (Phaseolus vulgaris L.). Publ. UEPG Ci. Exatas Terra, Ci. Agr. Eng., 6, 23-35. https://doi.org/10.5212/publicatio.v6i01.744

Xie, X., Pu, L., Zhu, M., Meadows, M., Sun, L., Wu, T., \& Xu, Y. (2021). Differential effects of various reclamation treatments on soil characteristics: an experimental study of newly reclaimed tidal mudflats on the east China coast. Sci. Total Environ., 768, 144996. https://doi.org/10.1016/j.scitotenv.2021.144996

\section{Copyright Disclaimer}

Copyright for this article is retained by the author(s), with first publication rights granted to the journal.

This is an open-access article distributed under the terms and conditions of the Creative Commons Attribution license (http://creativecommons.org/licenses/by/4.0/). 